\title{
THE RECOVERY OF THE FOREIGN ASSETS OF NATIONALIZED RUSSIAN CORPORATIONS
}

\author{
GEORGE NEBOLSINE
}

The Russian Communist revolution, ${ }^{1}$ directed against the property rights of the "non-labouring" classes, succeeded in overturning the existing economic order in Russia by means of sweeping legislation nationalizing, without compensation to the former owners, industry, banking, insurance, and shipping. ${ }^{2}$ Corporate

1 On November 7, 1917, the Communists overthrew the Kerensky Provisional Government which had succeeded that of the Tsar.

2 Specimen decrees affecting various businesses are given below:

Decrees Nationalizing Manufacturing Companies:

The Decree of June 15, 1918, declared the "hereinafter mentioned industrial and trading concerns . . . . with all their capital and properties, whatever form they might be in, the property of the Russian Socialist Federated Republics ...."

"Until further special action .... the concerns herein declared the property of the R. S. F. S. R. are to be regarded as gratuitously leased to tho former owners; the boards of directors and former owners finance them as before and also receive income from them as before."

The Decree of November 29, 1920 declared: "1. All industrial undertakings in the hands of private owners or companies, employing over five workers and using motor power, or employing ten workers without motor power, are declared nationalized."

"All the property, the affairs and capital of the concerns referred to in paragraph 1 , wherever this property is located and in whatever form it is, is declared the property of the R. S. F. S. R."

The Decree of December 10,1921, defined nationalization as being in effect: "(1) If the property has been taken over by an agency of the Government pursuant to the above decree or any equivalent decree; (2) if the management of the company has been taken over, or managers appointed; (3) if the operation or planning of the property is actually conducted at the expense of the Government." B. S. MaLTzMaN, LegisLation REGARdiNg INDUSTRY, Trade, Labor aND Transport (1923) 50 (Russian).

Decrees Nationalizing Banking Companies:

The Decree of December 14, 1917 :

"In the interests of the proper organization of national economic life, of the resolute eradication of banking and speculation, and of the complete liberation of the workers, peasants, and the whole labouring population from exploitation by banking capital ...

1. Banking is declared a State monopoly.

2. All existing joint stock banks and banking houses are amalgamated with the State Bank.

3. The assets and liabilities of the liquidated banks are taken over by the State Bank. 
activity was brought to an abrupt end, the property and assets in Russia of the private corporations affected by the decrees vere transferred to the State, shares of stock were seized, directors and shareholders meetings suspended. Abroad, fugitive directors and shareholders of the nationalized Russian companies have made various attempts to reconstitute themselves in an effort to salvage bank deposits and credits which Soviet agents have not been able to reach. ${ }^{3}$ In the numerous suits which have

4. The method of amalgamation of joint stock banks with the State Bank shall be determined by a special decree."

The Decree of January 26, 1918:

"1. The share capital (stock, reserve and special) of former joint stock banks are transferred to the State Bank of the Russian Republic on the basis of complete confiscation.

2. All bank shares are declared null and void, and payment of dividends of any kind whatsoever is unconditionally stopped.

3. All bank shares must forthwith be surrendered by the present holders to the local branches of the State Bank.

4. The holders of bank shares which they cannot produce must submit to the branches of the State Bank register records of the shares in their holding indicating their exact whereabouts.

5. The holders of bank shares who have failed to surrender them in accordance with paragraph 3 or to submit register records of their shares in accordance with paragraph 4, within a period of two weeks following the day of the publication of the present decree, are punished by confiscation of all their property.

6. All transactions and deeds of transfer referring to bank shares are unconditionally prohibited. Persons taking part in such prohibited transactions and deeds are punished with imprisonment up to three years."

The R. S. F. S. R. Constitution, July 10, 1918, c. II, § 3:

"(e) There is confirmed the passing of all the banks into the ormership of the Workmen-Peasants' State as one of the conditions of the emancipation of the labouring masses from beneath the yoke of capital . . ." Russian Comm. \& Ind. Bank v. Comptoir d'Escompte de SYulhouse, [1925] A. C. $112,120$.

The Decree Nationalizing Insurance Companies:

The Decree of December 1, 1918:

"1. Insurance of all kinds and forms, such as insurance against fire, insurance of transport, life, against accidents, hail, epizooty, bad crops, etc.; is declared to be the monopoly of the State. Note: Sifutual insurance of movable property and goods by co-operative organizations is carried out on a special basis.

2. All private insurance companies and organizations (joint stock share and mutual) are subject to liquidation on the publication of the present decree; former Zemstro (Popular Soviets') and mutual-municipal insurance organizations, operating within the boundaries of the Kussian Republic, are declared to be the property of the Russian Socialist Federative Soviet Republic.” First Russian Ins. Co. v. London \& Lancashire Ins. Co., [1928] 1 Ch. 922, 934 .

3 The variety and amount of assets belonging to Russian corporations in foreign countries is incalculable. The surplus funds of Russian insurance companies in New York state alone has been said to aggregate $\$ 6,000,000$. New York Times, May 30, 1930. The number of cases cited here from sis: or seven countries also indicates to some extent the volume of claims in- 
been brought before foreign tribunals the unprecedented character of many of the questions involved, entangled as they are with importunate political, economic, as well as legal considerations, has produced considerable confusion of reasoning. But although contradictory theories have been employed by the courts of different countries, and sometimes by the courts within the same jurisdiction, the resolution of the ultimate question, whether the Soviet government or the former owners are entitled to the property, has been answered with surprising unanimity. The conclusion is forced upon one that even where the Soviet government has been granted political recognition," the courts have, as a whole, strongly favored the former owners. In so doing they have given effect to a public policy which, in all non-socialistic countries, dictates a repudiation of communistic legislation.

volved. The following quotation furnishes an intriguing illustration of the variety of situations which have and are likely to arise:

"A perplexing problem, involving questions both of the effect of Soviet legislation and of State succession, is promised in Palestine. Certain Russian religious corporations, in particular, the Orthodox Palestine Socicty and the. Russian Ecclesiastical Mission, owned before the war extensive properties in the Holy Land, and built a number of churches, religious hostels, and hospices in the holy cities and in the neighborhood of holy sites. Local representatives of the societies in Palestine have continued to administer these properties since the war and claim that the sqcieties' ownership is unimpaired. The Soviet Government, however, has claimed that, in virtue of a decree of the Council of the People's Commissaries of January 28,1918 , these Russian societies have been wound up, and their movable and immorable property recognized as the property of the Soviet State. The Gorernment, therefore, declares that all the lands, hospitals and other buildings, and in general all other movable and immovable property of the said societies at Jerusalem, Nazareth, Haifa and Beirut and other places in Palestine or elsewhere, constitute the property of the Russian State. At the same time, they declare null and void all transactions which may have taken place in respect of such property without their consent and approval.

"The Russian societies, although called Imperial, and normally having as their President a member of the Imperial family, were quite independent of the State; and the question which may have to be considered is the effect of these decrees of the Soviet Government in dissolving the societies. No legal action has yet been brought in the courts of Palestine either by or against the Russian societies, so that the question of their legal status has not yet come up for judicial determination." Bentwich, The Soviet Government and Russian Property in Foreign Countries (1924) BR. YEARBoOK of INT. LAW 84 . It would be interesting to see how the avowedly atheistic government of Russia would fare before the World Court, as Mr. Bentwich suggests, in seeking possession of some of the most holy shrines of Christendom.

+ The principal countries which have recognized the Soviet government de jure are: Germany, April 16, 1922; Great Britain, February 1, 1924; Italy, February 7, 1924; France, October 28, 1924 ; Japan, January 1, 1925. Belgium, Holland, Switzerland and the United States have never recognized the Soviet government. THE ReCognition POLICY OF THE UNITED STATES, Information Service, For. Pol. Ass. (1926) 18. 
The problem has been presented before the courts of various countries in somewhat different settings. In the United States, the fact that the Soviet government has not been recognized has been a factor of considerable influence upon the attitude of the courts. Thus, as one of the resuits of non-recognition the Soviet government was denied capacity to sue in American courts.s The view was also taken in several early cases that the decrees of an unrecognized state were without effect in the United States." It is clear that such a principle : would permit Russian corporations to continue unimpaired in the enjoyment of their

5 The Rogdai, 278 Fed. 294 (N. D. Cal. 1920), 279 Fed. 130 (N. D. Cal. 1920) (libel against a vessel); The Penza, 277 Fed. 91 (E. D. N. Y. 1921) (semble); Russian Republic (R. S. F. S. R.) v. Cibrario, 235 N. Y. 235. 139 N. E. 259 (1923). For purposes of recovering assets of the Russian State in the United States, the former financial representative of the Kerensky government represents the Russian government. Lehigh Valley R. R. v. State of Russia, 21 F. (2d) 396 (C. C. A. 2d, 1927), certiorari denied, 275 U. S. 571, 48 Sup. Ct. 159 (1927). Likewise the Soviet Government may not be made party defendant in a tort action for illegal seizure of property in Russia. Wulfsohn v. Russian Government (R. S. F. S. R.), 234 N. Y. 372, 138 N. E. 24 (1923), reargument denied, 235 N. Y. 579, 139 N. E. 742 (1923); commented on in (1922) 31 YaLE L. J. 534; (1922) $3 J$ HARV. L. REv. 768. But title was allowed to be set up in the Soviet Government as a defense to an action by the former owner of a gold shipment. Banque de France v. Equitable Trust Co., 33 F. (2d) 202 (S. D. N. Y. 1929).

6 Sokoloff v. National City Bank, 239 N. Y. 158, 145 N. E. 917 (1924), where the defense of nationalization of the bank's assets in Russia was rejected by the court in a suit by a depositor who had agreed to accept payment there. The court said: "Courts of high repute have held that confiscation by a government to which recognition has been refused has no other effect in law than seizure by bandits or by other lawless bodies." 239 N. Y. at 164,145 N. E. at 918. Russian Reinsurance Co. v. Stoddard, 211 App. Div. 132, 207 N. Y. Supp. 574 (3d Dep't 1925); Bourne v. Bourne, 241) N. Y. 172,148 N. E. 180 (1925). See James \& Co. v. Rossia Ins. Co.. 247 N. Y. $262,269,160$ N. E. 364,366 (1928) : "We have never recognized that government. Its decrees are treated as nullity except in so far 35 there is need to recognize them for the purpose of promoting justice." A similar limitation upon the stringency with which this theory is to be applied was suggested in Sokoloff v. National City Bank, sumra.

? The view has been attacked by Dickinson, Rocent Recognition Cases (1925) 19 AMr. J. INT. L. 263; Connick, The Effect of Soviet Decrees in America (1925) 34 YALE L. J. 499: and Fraenkel, The Juristic Status of Foreign States, Their Prop:rt" aind Their Acts (1925) 25 CoL. L. Rev. 544, on the grounds that the absence of political recognition cannot affect the question of private rights dependant upon the internal operation of Russian law. The opposite view is urged by European authorities. TIEfExaU, L'ExISTEXCE A L'ETRANGER DES SOCIÉTÉS RUSSES (1928). See also Houghton, The Validity of the Acts of Unrecognized de facto Governments in the Courts of Nom-recognized States (1929) 13 IIn:N. L. REv. 216, and The Position of Unrecognized Governments Before the Courts of Foreign States (1929) 4 IxD. L. J. 445. A full discussion of the implications of this question is impossible in the compass of this article. But see notes $76,77,78,79$ and 80 injra. 
rights and privileges as foreign corporations in the United States so long as the Soviet government remained unrecognized.

In the case of Russian Reinsurance Co. v. Stoddard, ${ }^{8}$ however, a change took place in the courts' view of the problem. The reasons for this shift were threefold: the feeling that despite the absence of political recognition, a more realistic view ought to be taken of what had occurred in Russia; the criticism of commentators who argued that the theory employed by the earlier decisions was incorrect; ${ }^{9}$ and the fear that, in some of the growing number of countries which had recognized the Soviet government, the debtors of Russian companies compelled to pay in the United States might be subjected to double liability. ${ }^{10}$

In the Stoddard case the New York Court of Appeals refused to assume jurisdiction in a suit brought by fugitive directors of a Russian insurance company to recover a statutory deposit made under the insurance law of New York. The decision was based upon a denial of the competency of the directors to act for the corporation, and, more directly, upon the danger to the defendant of a second suit by the Soviet government in a country where it had been recognized. In his discussion of the case Judge Lehman drew some far-reaching conclusions with reference to the effect that should be granted by American courts to Soviet legislation. The view of the earlier cases that the problem hinged purely upon political recognition was passed over. The private rights and obligations of individuals affected by Soviet legislation, he declared, presented a judicial, not a political question; moreover, the absence of political recognition should not blind the courts to the actual state of affairs in Russia:

"The courts in considering that question assume as a premise that until recognition these acts are not in full sense law. Their conclusion must depend upon whether these have nevertheless had such an actual effect that they may not be disregarded." ${ }^{11}$

After a critical examination of the history of the plaintiff company with a view to determining the "actual" effect of the nationalization decrees, Judge Lehman concluded that the company, if it existed at all in the forum, was an abstraction rather than an actuality and in Russia was certainly without existence. Under these circumstances, to permit recovery by the plaintiffs would be contrary to "common sense and justice." While this decision did not expressly overrule the former theory, in ascrib-

8240 N. Y. 149,147 N. E. 703 (1925).

${ }^{9}$ Particularly Dickinson, op. cit. supra note 7 , which was published a few days before the decision in the Stoddard case was rendered.

10 Supra note 4. It will be noted that a number of states recognized the Soviet Government in 1924 immediately prior to the Stoddard case.

In Supra note 8 , at 158,147 N. E. at 705. 
ing some legal consequence to the actual results of Soviet legislation, it seemed, as Judge Crane pointed out in his dissent, to be doing by indirection what the court had said it would not do directly. The pragmatic approach, however, met with the approval of commentators ${ }^{12}$ and a similar line of reasoning was employed in several subsequent decisions. ${ }^{23}$ Why then, may it be asked, did the New York Court of Appeals repudiate the reasoning of the Stoddard case in its latest decision of Petrogradshy MIejdunarodny Kommerchesky Bank v. National City Bank? "s

The facts of the Mejdunarodny case are very similar to those of the Stoddord case. The plaintiff, a Russian bank, as represented in the suit by three survivors of 'the last board of directors, sought to recover a deposit in the defendant bank. The court held that a recovery must'be allowed. In reaching this conclusion Chief Judge Cardozo came to grips vith the three outstanding issues of the problem:

(1) Could the corporation sue in New York despite its nationalization by the Soviet government?

(2) Had the directors, who brought the suit, authority to act in behalf of the corporation?

(3) Was there a risk that the debtor would be made to pay

12 Dickinson, The Russian Reinsurance Company Cases (1925) 19 Ass. J. INT. L. 753; (1925) 35 YAIE L. J. 98; (1925) 11 CoRN. L. Q. 99; and some of the articles cited supra note 7. Criticism was severe, however, by Scheftel (1925) 52 CLUNeT 1074, who described the decision as 3 "denial of justice inspired by political apprehensions ... It would be difficult to find another precedent, where a national tribunal had refused to apply the principles of established law becsuse of their incompatibility with the political conceptions and the jurisprudence of foreign states."

13 Severnoe Securities Corp. ₹. Westminster Bank, 214 App. Div. 14, 210 N. Y. Supp. 629 (2d Dep't 1925). This decision goes to the extent of citing the Miulhouse decision in the House of Lords, supra note 2, and then going on to say: "The record here shows . . . [that] all Russian insurance companies were destroyed by the Soviet government and their properties confiscated. If that situation be recognized in England, plus the further recognition by the British government of the de facto character of the Soviet government of Russia, it is exceedingly difficult to say here and now that a suit will not lie in England by and on behalf of the Soviet government against the defendant ..." 214 App. Div. at 19, 210 N. Y. Supp. at 634. How this doubt could be read into the Milhouse case is dificult to comprehend. Compare also Banque International de Commerce de Petrograd v. National City Bank, 133 Misc. 527, 233 N. Y. Supp. 255 (Sup. Ct. 1929) (lower court decision in the Mejdunarodny case). But the Stoddard case was distinguished in First Russian Ins. Co. v. Stoddard, 212 App. Div. 841, 207 N. Y. Supp. 837 (3d Dep't 1925), aff'd, 240 N. Y. 601, 148 N. E. 722 (1925), reargument denied, 240 N. Y. 643,148 N. E. 740 (1925). Since the Superintendent of Insurance held the property in this case there could be no danger of a second recovery against him in another jurisdiction. Judge Pound in the dissent, however, argued that the company was in fact nonexistent.

I屯 253 N. Y. 23,170 N. E. 479 (1930). 
the debt over again to the Soviet government in a country where recognition had been accorded?

In the following discussion of these three issues, the decisions of the American and foreign courts will be brought together in order to compare the views that have been held on each of the above questions and to discover the significance of the Mejdunarodny case in the treatment of the assets of nationalized Russian corporations.

CAN A RUSSIAN CORPORATION SUE IN A FOREIGN JURISDICTION DESPITE ITS NATIONALIZATION BY THE SOVIET GOVERNMENT?

The usual defense to actions brought by nationalized Russian corporations in both American and foreign courts has been the plea that the corporation no longer exists and therefore cannot appear before the court as a party to a suit. The issue is thus at the outset presented in a manner leading most naturally into a consideration of legal abstractions concerning the continued existence of a corporate personality despite the vicissitudes of its career subsequent to the decrees of nationalization. But the opportunity is not lacking for the courts to consider the economic and social consequences of their decision, and, as has been observed, there is a strong temptation to deny effect to Soviet legislation wherever reasons can be found for doing so. The ingenuity of the courts is testified by the profusion and by the variety of theories used to achieve this result.

Where an alleged foreign corporation seeks to sue, or is sued, the courts will ordinarily look to the laws of the state of incorporation to determine whether it is a corporation. As Holdsworth has said: "corporate life and form . . . cannot exist without the permission of the state, express, presumed or implied." ${ }^{15}$ This premise, which is indeed the prevailing theory of Anglo-American law, appears in the Restatement of the Conflicts of Laws as follows:

"If a corporation is dissolved by the state of incorporation, another state will recognize that the association has ceased to have legal personality; and if the exercise of legal personality is suspended by the state of incorporation, this suspension will be recognized in another state." 10

The argument against allowing the corporation to sue, therefore, starts with the proposition that effect must be given to

269 HoLDSWORTh, HISTORY OF ENGLISH LAW (1926) 48; see Dewey, The Historic Background of Corporate Legal Personality (1926) 35 YALE L. J. 655.

18 Confucts of Laws Restatement (Am. L. Inst. 1930) Proposed Final Draft No. $1, \S 167$. 
the laws of the foreign state, whether it be recognized or not. It is insisted not only that the Soviet decrees have dissolved the corporations in Russia but that the companies have ceased to exist in fact as well as law. The majority of American, English and French courts, however, despite this argument based upon what appears to be accepted doctrine, have allowed Russian corporations to sue in the forum. In order to meet the arguments advanced by parties claiming that the corporation has ceased to exist, four distinct theories have been used:

First, in countries where recognition has not been accorded to the Soviet government, legal effect may be denied the decrees.

Second, in countries where the Soviet government has been recognized and the decrees are accepted as the law applicable to the question it may be argued that by their very terms the decrees do not dissolve the Russian corporations.

Third, the Holdsworth premise may be qualified as follows: where the corporation in question has reconstituted itself in the forum it is to be regarded as a de facto corporation and beyond the reach of the legislation of its country of origin, though corporations not having a de facto existence in the forum are to be regarded as dissolved.

Finally, a fourth possibility presents itself, that of denying the Holdsworth premise altogether and simply allowing the corporation to sue in the forum on the ground that it is primarily a power for the forum rather than the state of incorporation to concede, if its public policy so requires.

American Decisions. The first method of evading the nationalization decrees and finding that the corporate existence has not been terminated was employed generally prior to the Stoddard decision by American courts. But in that case the assumption that absence of recognition alone was a sufficient ground upon which to circumvent the Holdsworth premise vas severely attacked. The importance of the 1Lejdunarodny decision lies in the manner in which it meets the reasoning of the Stoddard case on this point.

In effect the contention of Chief Judge Cardozo is that, even assuming that the Soviet decrees were intended to extinguish the life of the corporation in question, the courts of a foreign state are not obliged to give them such effect:

"There is a distinction, not to be ignored between the life of a human being and the life of a persona ficta, the creature of the State. When a human being dies, his death is equally a fact whether it was brought about legally or illegally. . . . The event is not conditioned by the juristic quality of the cause. But in respect of juristic beings, the quality of the cause may determine the event as well. The personality may continue un- 
impaired until law rather than might shall declare it at an end." ${ }^{17}$

It is not quite clear from this reasoning whether Chief Judge Cardozo has abandoned the theory of non-recognition as a sufficient ground in itself for denying effect to the decrees. But there are strong indications in another passage of the opinion that he finds support for refusing the decrees any application in the present instance on the grounds of public policy, an argument which verges on the fourth of the theories enumerated above. The decrees, it is contended, will be given effect only where the public policy of the forum requires that this should be done. But, he declares, there is no shelter in this exception for rapine and oppression:

"We do not recognize the decrees of Soviet Russia as competent to divest the plaintiff of the title to any assets that would otherwise have the protection of our law. At least this must be so where the title thus divested is transferred to the very government not recognized as existent." ${ }^{18}$

It might be suggested that this fourth ground would alone be sufficient to achieve the result. Is not the problem essentially that of the powers which the forum shall confer upon the persons before it? The habit of looking to the country of origin of the corporation for guidance as to the treatment to be accorded to it is limited by the public policy of the forum when the purpose of the association is illegal in the forum. Why then cannot the forum also determine for itself whether a foreign corporation has the power to sue in its own courts without being bound by the conclusions reached as to this matter abroad?

But even granting that the corporation may not have been dissolved by a competent legal authority, the reasoning of the Stoddard case still remained to be met. Had not the physical changes attending the decrees, whatever their legal nature, produced such an "actual effect" that the corporation no longer possessed the power to sue? This was considered by Judge Cardozo in the following portion of his opinion:

${ }^{27}$ Supra note 14 , at 30,170 N. E. at 481 .

18 Ibid. $29,170 \mathrm{~N}$. E. at 481 . The passages quoted above might be compared with the opinion rendered by the same judge in Fred S. James \& Co. v. Second Russian Ins. Co., 239 N. Y. 248,146 N. E. 369 (1925), where the defense advanced by a Russian corporation of extinguishment by Soviet decree was rejected for much the same reason: "We deal now with the single question whether the defendant has an existence sufficient to subject it to suit in the domestic forum. That is a question which the law of the forum will determine for itself . . ." 239 N. Y. at 256, 146 N. E. at 371 . 
"The corporation once existing, the burden was on the defendant to overthrow the presumption of continuance and to show that life had ceased. We cannot say upon this record that the burden has been borne. If we look to the analogies of our own law, the conclusion is not doubtful. Neither bankruptcy, nor cessation of business, nor dispersion of stockholders, nor the absence of directors, nor all combined, will avail without more to stifle the breath of juristic personality. The corporation abides as an ideal creation, impervious to the shocles of these temporal vicissitudes. Not even the sequestration of the assets at the hands of a receiver will terminate its being." 20

From this reasoning it followed that, despite the legislation which had resulted in stripping it of most of the attributes of corporate activity, the Russian corporation still existed, at least for the purpose of recovering its assets in New York. That this treatment of the question is not entirely unprecedented is evident from an examination of the cases in England.

English Decisions. By virtue of the fact that Great Britain recognized the Soviet government as early as 1921.9 the use of non-recognition as a theory upon which to base a refusal to give full effect to the Soviet nationalization decrees has been unavailable to the English courts. The problems, however, have been essentially the same as those facing the courts of the United States. And the English decisions have not been at a loss to find other theories in support of their conclusions.

Several of the early cases raising the issue of the competency of a nationalized Russian corporation to sue were decided by the King's Bench against the plaintifi corporation. Thus where a Russian bank was attempting to collect from one of its debtors the defense was raised that the bank had become extinct.a1 In deciding that the plaintiff in fact and in law had ceased to exist, Scrutton, L. J. declared:

"If the artificial person is destroyed in its country of origin, the country whose law creates it as a person, it appears to me it is destroyed everywhere as a person." $=2$

Likewise, according to this view, it was impossible for a bank which had tendered its debt to recover bonds deposited with the defendant as security, ${ }^{23}$ or for a British creditor of a Russian

19 Supra note 14 , at 31,170 N. E. at 482 . Citations to cases in the opinion are omitted in the passage quoted.

20 De facto recognition took place by the Treaty of Commerce, March 16, 1921, (1928) 18 DE MLARTENS (3d) 684.

21 Banque Internationale de Commerce de Petrograd v. Goukassow, [1923] 2 K. B. 682.

22 Ibid. 691.

23 Russian Comm. \& Ind. Bank v. Comptoir d'Escompte de Mrulhouse, [1923] 2 K. B. 630 . 
company to garnish a debt owed to the non-existent company by the defendant.24

On an appeal of the second of these cases to the House of Lords, in Russian Comm. \& Ind. Bunk v. Comptoir d'Escompte de Mulhouse, ${ }^{25}$ the holding of the lower court was reversed and the Russian bank allowed to recover. By this decision the House of Lords established the doctrine, which has not since been questioned by the English courts, that the decrees of the Soviet government did not dissolve the Russian companies but merely seized their assets in Russia. ${ }^{26}$ This view, which represents the second of the theories mentioned above, was summed up by Lord Sumner in a later case as follows:

"In these decrees not only the word 'dissolution' but the thing itself was carefully avoided, no doubt for solid practical reasons." 27

But, again granting that the decrees by their terms had not extinguished the Russian corporations, the English courts also found themselves still faced with the fact that the decrees, in actual effect, had destroyed the coporations in Russia by annulling shares, seizing assets, and terminating all business activity. The point was met in England as it was recently met by Chief Judge Cardozo. In dissenting from the lower court decision in the Mulhouse case Judge Atkin declared:

"We are quite familiar in our law with the position that a company may lose all its assets, may have no directors administering the affairs of the company, or have the powers of the directors transferred in the course of liquidation to an officer of the court, may have all its assets distributed amongst the shareholders, and yet remain an entity until a formal dissolution." ${ }^{2 s}$

This line of thought was later elaborated by Judge W'right:

"In any case, annulment of shares of stocks, whatever it may

${ }^{24}$ Sea Insurance Co. r. Rossia Ins. Co., 17 Ll. L. R. 316 (1924).

${ }^{25}$ Supra note 2.

${ }^{26}$ In the following cases various Soviet decrees were similarly construed: Banque Internationale de Commerce de Petrograd v. Goukassow, [1925] A. C. 150 (bank); The "Jupiter," [1927] P. D. 250 (navigation company); Woronin, Leutscheg \& Cheshire v. Huth, K. B. Div. May 2, 1928 (unreported), see (1928) 55 CLUNET 756 for transcript of the case and note (manufacturing company) ; First Russian Ins. Co. v. London \& Lancashire Ins. Co., supra note 2 (insurance company). Service upon the representative of a Russian company in England was upheld in Sabatier v. The Trading Co., [1927] 1 Ch. 495.

27 Employers' Liability Assurance Corp. v. Sedgwick, Collins \& Co., [1927] A. C. 95, 108.

${ }^{28}$ Supra note 23 , at 664 . 
mean, would in my opinion not destroy the existence of the company . . There is indeed no reference in the decrees now being considered, to the liquidation of the companies; their enterprises were simply taken as going concerns. It may be that in Russia the plaintiff company had no practical existence; that its property in Russia was taken from it, and its statutes could not have working effect; but I see no reason to find that as an entity it was dissolved and I find that it was not dissolved but still exists . . ." 29

It is interesting to note that one English judge has expressed doubts as to the validity of the premise that a dissolution of a corporation by a foreign state is binding upon the forum. While not going so far as to dissent on this ground from the lower court decision in Banque Internationale de Petrograd v. Goukassow, Judge Atkin made the following interesting remarks:

"We are considering whether the alleged actor exists, and in determining that issue, it appears to me that the Court must apply its own law, the lex fori. Whether the plaintiff in an English court is dead or alive would be determined on an issue of fact by English evidence and procedure; and it appears to me quite irrelevant to consider whether the Courts of the country where he was domiciled or where the cause of action arose, would hold him to be alive or dead." 30

But the judge goes on to say that on principle the plaintiff is dead, and principle must be followed. While there are only dicta attacking the prevailing Anglo-American doctrine on this issue, these dicta appear to be based upon sounder thought than the prevailing view itself, as applied to the question at hand. Without denying that Holdsworth's view as codified in the Restatement is applicable in the ordinary run of cases, it would involve no departure from the doctrine of stare decisis for the courts to hold that the public policy of the forum admits of a modification of the general principle in this sui generis situation.

In search of an additional reason to fortify its result in allowing the Russian corporation to recover, the court in the Mulhouse case sought to establish an estoppel against the Soviet government to deny that the decrees still permitted branches of the corporations abroad to do business. ${ }^{32}$ This reasoning ap-

${ }^{23}$ Woronin, Leutscheg \& Cheshire v. Huth, supra note 26.

30 Supra note 21, at 693 .

31 It was pointed out that as late as 1922 drafts were drawn by a Jiutual Credit society in Russia against the London branch of the supposedly nationalized Russo-Asiatic Bank in favor of the Soviet Trade Delegation, an official body representing the Soviet Government. These draits were honored and paid in London. See also First Russian Insurance Co. v. London \& Lancashire Insurance Co., supra note 2, holding that the Soviet decrees, while applying to all insurance companies in Russia, did not affect the plaintiff's right to do business outside of Russia. 
proaches the third of the theories suggested above, namely, that a corporation which has a de facto existence in the forum may maintain suit. It has, however, been left undeveloped by the English courts, the principle reliance upon the de facto theory having been in France.

French Decisions. The French courts more frequently than any others have had questions concerning Russian corporations before them. The quantity of cases is explained in part by the great number of Russian enterprises which had branches in France and in part by the presence there of many refugee directors and shareholders of Russian companies. But the value to us of the decisions is somewhat diminished by the fact that under French law the courts are not competent to take jurisdiction in all cases involving foreign corporations not authorized to do business in France..$^{32}$ In many cases, consequently, the court has merely held itself incompetent to act, though under similar circumstances in England or the United States a court might have taken jurisdiction.

Prior to recognition of the Soviet government, which occurred in $1924,{ }^{33}$ the French courts appear to have allowed no legal validity to the Soviet decrees of nationalization..$^{34}$ Since recognition has been accorded, however, Russian corporations are deemed to have been dissolved in Russia, and Russian corporations in France have been subjected, by order of the Procurator of the Republic, to "provisional administration" and "measures of conservation." ${ }^{35}$ But this policy has not been carried to its

322 Rousseat, Sociétés Commerciales (1921) 449: "It is the law at the present time that while such companies cannot act as plaintiffs, they can be brought before the French tribunals as defendants as de facto corporations ...."

${ }^{33}$ Supra note 4.

${ }^{34}$ The Paris branch of a Russian bank was held liable on a draft drawn by a subsequently nationalized branch of the same bank in Russia. Hornstein v. Banque Russo-Asiatique, Trib. Comm. Seine, April 15, 1924 (1927) 54 Clunet 1075; semble, Kharon v. Banque Russe pour le Commerce et l'Industrie, Trib. Civil Seine, May 20, 1921 (1923) 50 CLuNer 533. In an action by directors of a Russian company to recover deposits from the defendant, the plaintiff was recognized as still an existing juristic person, but the defense that the directors were not qualified to represent the company was sustained. Banque Industrielle de Moscou v. Banque des Pays du Nord, Trib. Civil Seine May 21, 1924 (1927) 54 CLUNET 350. It was held that the business of the company might be conducted in Paris, and shareholders' meetings held at the new domicile were valid if a sufficient number of shareholders were notified. Vlasto v. Banque Russo-Asiatique, Trib. Comm. Seine, April 26, 1922 (1923) 50 Cluner 933. See Champcommunal, La condition des Russes a l'étranger specialement en France (1924) 19 REv. DE DR. INT. PR. 321, 525; see Grouber and Tager, Le point de vue de la jurisprudence froncaise (1924) 51 Clunet 8.

ss Ordinances dated Oct. 22 and Nov. 29, 1924 (1925) 52 Clunet 530. 
complete conclusion, for where the Russian companies have a de facto existence in France, either by virtue of a branch office or by reconstitution in some way, directors may be successful in their claims against assets in France. Thus where a French bank had been organized with funds belonging to a branch of a Russian bank, neither the Soviet nationalization decrees nor the above-mentioned ordinances of the French government affected it. ${ }^{38}$ And where the Paris branch of a Russian bank had become "the center of its activities" and had "lost the character of a branch," ${ }^{3 \pi}$ or where a private corporation had acquired a domicile de facto in France ${ }^{\text {ss }}$ the same result has been obtained. On the other hand where the Russian company is unable to show proof of any de facto existence in France, it cannot sue its debtors before the French courts. ${ }^{39}$ In several decisions there seems to have been a departure from the theory of de facto corporations but such departure now appears to have terminated. ${ }^{* 0}$

See André-Prudhomme, La Reconnaissance en France du gouvernement des Soviets et ses Conséquences juridiques (1925) 52 CLUNer 318.

${ }^{36}$ Banque générale pour. le commerce ètranger v. Jauudon, Trib. Civil Seine, December 23, 1924 (1925) 52 CLUNeT 419.

${ }_{37}$ Banque Russo-Asiatique, Trib. Civil Seine, Mlarch 23, 1925 (1927) 54 Clunet 352; Banque Russe pour le Commerce Etranger, Trib. Civil Seine, MIay 3, 1926 (1927) 54 Cluner 358.

${ }^{38}$ Selikman v. Soc. de Naphte de Bakou, Trib. Comm. Seine, April 12, 1926 (1927) 54 CLUNET 357 (Russian company set up defense of the court's lack of jurisdiction, it being a foreign company). Scmble, Teslento v. Banque Russo-Asiatique, Cour de Paris, July 22, 1929 (1929) 56 Cuunet 1110; National City Bank v. Renault Russe, Trib. Comm. Seine, July 12, 1929 (1929) 56 Cluner 1122. See discussion of Mlazeaud, De la Nationalité des Sociétés (1928) 55 Cluset 30.

${ }^{39}$ Nord de Moscou v. Phenix Espagnol, Trib. de Paris, June 13, 1928 (1929) 56 Clunet 119; Banque de Sibérie v. Vairon, Cour de Bordeaux, January 2, 1928 (1929) 56 CLUNET 11j. But compare Zelenoff v. Banque de Commerce de Sibérie, Cour d'appel de Paris, January 31, 1928 (1928) 55 CLUNeT 679, where in a suit against the same company the court gave judgment for the plaintiff.

to Where the plaintiffs, creditors of a Russian bank, have sought to enforce their claims against the Paris branch of the bank, zome of the decisions even after recognition of the Soviet Government by the French Government have held the branch not liable for debts of the principal office on the theory that the principal office still had a legal existence in Russia. Karagoulian v. Banque Russe pour le Commerce et l'Industrie, Cour de Paris, May 17, 1927 (1928) 55 Cluver 131; Rabinovitch v. Banque Russe pour le Commerce Etranger, Trib. Comm. Seine, BIay 15, 1925 (1927) 54 Clurvet 354; Dame Krivitzky v. Banque Russe pour le Commerce Etranger, Trib. Comm. Seine, November 19, 1927 (1928) 55 Clunet 132. Eut in Zelenoff $v$. Banque de Commerce de Siberie, supra note 39 , the court refused to follow the above decisions and held the branch bank liable on the grounds that it had in fact acquired a domicile in France and could not escape liability by referring creditors to the non-existing principal office in Russia. Cf. Kahn v. Soc. d'assurances Rossia, Cour d'appel de Paris, March 8, 1928 (1928) 55 CLUNeT 682. 
The French doctrine has the disadvantage of preventing the collection of debts by the Russian companies which have not been successful in establishing their de facto character. This, in effect, makes a gift of the debt to the debtor, a result that seems even less justifiable than placing the funds in the hands of a minority of the former directors and shareholders of the company. The harshness of the doctrine has been somewhat mitigated by a certain leniency in finding the formation of a de facto corporation, as well as by the expedient suggested by one court, in rejecting the demand of directors, that a liquidator or a judicial administrator be appointed to hold the assets. ${ }^{42}$ But the French courts have not regarded the act of dissolution, as distinguished from the confiscation of assets, as contrary to the public policy of the forum. In deciding otherwise the New York Court of Appeals in the Mejdunarodny case would appear to have achieved a more desirable result. For the purpose of collecting debts abroad it would certainly seem feasible to hold that the company still existed, and this result can be reached whether recognition has or has not been accorded to the nationalizing government.

German Decisions. There have been very few decisions in Germany with reference to claims to the assets of nationalized Russian corporations. But one case was so hotly contested before the Kammergericht that German jurisprudence upon the question has been considerably clarified. In Ginsberg v. Deutsche $B a n k,{ }^{42}$ creditors of a Russian corporation sought recovery of a debt by attaching the deposit of the Russian company in the Deutsche Bank. In defense it was urged that, since the company had been dissolved as a legal entity in Russia, there was no longer any debtor and consequently no debt. On appeal, the Kammergericht reversed the holding of the lower court, and granted the creditor an attachment. In rendering its decision the court declared:

"The decree must be regarded as a political declaration announcing a program for the future, not as a law having immedi-

41 Nord de Moscou v. Phenix Espagnol, supra note 39; approved by Picard and Tager (1929) 56 CLUNET 131, 133: "In fact, since the company may have assets abroad, which are not reached by the decrees of nationalization in so far as they expropriate without compensation, it survives until dissolution for two reasons. First, as a de facto company ..... In the second place, if the company is not continuing as a de facto company, it must be recognized as existing at least for purposes of liquidation. This is a rule of our law which the tribunals have not hesitated to apply to nationalized Russian companies."

42 Kammergericht, Berlin, March 3, 1925 (1925) I OSTRECHT 163. 
ate effect, and referring to a future decree for the annihilation of the banks. But no such decree was ever executed." 43

The decision was severely criticized by Dr. Wohl," who took the position that the Russian banks were dissolved despite the fact that no decree of nationalization mentions the dissolution of joint stock companies. He contends that the decrees which radically transformed the whole economic order in the direction of pure state ownership did not halt "directly in the face of the fictitious-according to the prevailing Russian theory-juristic personality of the joint stock companies."

On a rehearing the Kammergericht reversed its former view, giving judgment against the plaintiff creditor of the Russian bank. The decrees, it declared, destroyed the legal entity of the Russian bank and so left nothing which the plaintiff could sue. The question of the continuation of the corporate entity was discussed by the court as follows:

"In the previous suit this question was answered by the statement that it could not be established with certainty whether a legal nationalization of the Russian banks had taken place with the effect that the said banks had thereby lost their legal personality. However, this opinion can no longer be upheld today. Professor Schondorf's consultation on this subject shows that the decree of 14th December 1917, which was published on 17th December 1917, must be construed not only as a political declaration but as an act of nationalization. The nationalization involved not only a confiscation of the property of the banks, but also the loss of their legal personality, since the former private banks have now been transformed into Departments of the Peoples (State) Bank; their organization was completely destroyed. This destruction must also be held valid for the territory of the German Reich. The bank cannot exist in Germany when it no longer exists in Russia. Nothing different can be understood under Article 30 of EGBGB." $\approx$

Thus the German courts, in denying that the corporation has continued as a legal entity capable of suing in the German courts, have swung to a position opposed in principle to that of the recent English and American decisions.

Swiss Decisions. As the German, so the Swiss courts have considered but few cases bearing upon the nationalized Russian corporations. In an early decision ${ }^{* 0}$ it was held that the Mejdun-

43 Ibid. 164.

14 Wohl, The Nationalization of Joint Stock Banking Corporations in Soviet Russia (1927) 75 U. of PA. I. REv. 385, 527, 622, originally published in (1925) 1 Ostrechi 26,113, 163. This article was answered by Rabinowitsch, Das ausländische Vermögen der in Sowjetrusaland nationalisicrtcre Unternehmungen (1926) 2 OSTRECHT 1168.

45 (1928) JURISTISCHE WOCHENSCHRIFT 1232.

46 Comptoire d'Escompte v. Sosnowice, Trib. de Genere, Novembar 22. 1920 (1921) SEMAINE JUdictare 82. 
arodny Bank might still be represented by its former directors. But in the case of Banque Internationale de Commerce de Petrograd $v$. Hausner, where the same bank appeared as plaintiff, the Federal Tribunal reversed the holding of the lower court in favor of the plaintiff upon the ground that the legal status of a branch of a corporation depended upon that of the principal office, and that the absence of recognition by Switzerland did not prevent Russian law from operating in Russia. If the principal office had ceased to exist, it was argued, the branch also ceased to have any juridical personality. Holdsworth's theory of the corporation finds expression in the following sentence of the opinion:

"The existence of the branch, as such depends ... . upon that of the principal office, the existence of a branch being impossible without the principal office upon which this secondary place of business depends. . . . Thus if their [the decrees] effect is such as to terminate the existence of the principal office in Petrograd, the existence of a branch capable of taking legal action in Switzerland will not be admitted." 47

Thus. the highest tribunal in Switzerland denied any legal personality to the plaintiff corporation and, on rehearing, ${ }^{48}$ affirmed its decision.

A recently reported decision of the Supreme Court of Sweden, ${ }^{49}$ allowing recovery by a Russian bank of a deposit in Sweden, would imply that this court has aligned itself with the AngloAmerican view despite the fact that Sweden has recognized the Soviet government.

It will be noted in summary that there is a split between the Anglo-American decisions on the one hand and the French, German and Swiss on the other as to the legal theory applicable to the situation presented by the nationalized Russian companies. The disagreement does not follow from recognition or non-recognition of the Soviet government; that some continental courts follow a somewhat stricter view of the applicability of Soviet law in these cases than do the Anglo-American courts is perhaps rather attributable to differences in legal system. But the actual results of the decisions with respect to the disposition of the assets do not appear to be as varied as are the theories concerning the right of the corporations to sue. For, as will be seen below, the effect granted to the Soviet decrees in jurisdic-

47 Tribunal Federal, December 10, 1924 (1925) 52 CLUNET 488, 489.

48 March 11, 1925 (1925) Journal des Tribunaux 529.

49 A newspaper report printed in the RousKoe Slovo of New York, April 10, 1930, asserts that the Paris branch of a Russian bank seeking to regain a deposit in a Swedish bank was allowed recovery by the Supreme Court of Sweden on the grounds that Soviet decrees were effective only within the territories of the Soviet Republic. 
tions which acknowledge the dissolution of Russian corporations is strictly limited, so that former owners will not be denied recovery of their property even where the corporation is deemed to have been effectually dissolved.

\section{RIGHTS OF DIRECTORS AND SHAREHOLDERS}

The revolutionary upheaval that occurred in Russia resulted in the complete disorganization of the normal life of Russian corporations. Directors and shareholders were forced to suspend their corporate activities. Corporate records were lost or destroyed, share certificates were confiscated. In exile, surviving directors and shareholders have met and attempted to reorganize themselves for the purpose of continuing to do businss, or to recover the assets of the corporations in which they are interested. Under these strained and unusual conditions, representatives of the corporation come into court with no pretence at strict compliance with all the requirements of their corporate charter, by-laws, and the laws under which the corporation was organized. Meetings of directors and shareholders are held, if at all, away from the principal office; directors are frequently holding over beyond their appointed term; shareholders have difficulty in producing strict proof of their interest in the company; agents purport to act on the basis of powers granted by boards of directors the members of which may have died or disappeared long since.

Aside from the question as to the continued existence of a corporate personality, then, there arises the difficult and more practical task of determining when the officers or other interested parties who present themselves before the court have made a sufficient showing of authority to be permitted to represent the corporation in litigation.

Directors. The effect of non-compliance by the directors with the provisions of the charter as to the place of meeting, terms of office and similar provisions was brought out in the Stoddard case where recovery by the directors was denied. In a later case, however, another New York court appears to have taken a more liberal view. In permitting directors to organize an American company as the successors of the Russian company the Appellate Division declared:

"Under the circumstances in the case at bar, while the general powers of the directors of the Rossia company in Paris may be open to question, yet it will be assumed that their powers continue at least to the extent of preserving the assets of the cor- 
poration and holding the same for the benefit of the corporation and of its creditors." 50

On appeal to the Court of Appeals the decision was affirmed, the court referring to the powers of the directors as follows:

"When old institutions have fallen and none which we will recognize have succeeded, how shall we deal with foreign owners of property within our jurisdiction? We cast aside rigid rules made to control other conditions. We insist upon honest conduct, but when the morality of the proceedings satisfies us as a court of equity, we will not obstruct the conservation of property -. It [the corporation] was half dead and half alive. We make no effort to define the authority of its directors as such. We do hold that these proscribed individuals fleeing from the fury of the revolution retained the power to conserve property in this country as far as the courts of New York can protect it." 51

In the Mejdunarodny case the objections that the three surviving directors had never been re-elected to office after the expiration of their term and that the only meetings had been held at Paris rather than Petrograd, as required by the charter, were overruled. Chief Judge Cardozo treated the question of the authority of these directors to act for the company as follows:

"The directors who made the deposit in the name of the corporation or continued it in that name now ask to get it back. Either it must be paid to the depositor, acting by them, or it must be kept here indefinitely. Either they must control the custody, or for the present and the indefinite future it is not controllable by any one. The defendant expresses the fear that the money may be misapplied if the custody is changed. The fear has its basis in nothing more than mere suspicion. The directors, men of honor presumably, will be charged with the duties of trustees, and will be subject to prosecution, civil or criminal, if those duties are ignored. The defendant is not required to follow the money into their hands and see how they apply it. Its duty is to pay." 52

This decision, in agreement with the view of the lower court in the Stoddard case, ${ }^{53}$ seems to have overcome former fears of

so Fred S. James \& Co. v. Rossia Ins. Co., 220 App. Div. 404, 409, 221

N. Y. Supp. 739, 744 (1st Dep't 1927).

51247 N. Y. $262,270,160$ N. E. 364,367 (1928).

52 Supra note 14 , at 40,170 N. E. at 486 .

${ }^{53}$ Supra note 6. This view had been held in Joint Stock Co. v. National City Bank, 240 N. Y. 368, 148 N. E. 552 (1925). See Beha v. Second Russian Ins. Co., 225 App. Div. 92, 232 N. Y. Supp. 282 (1st Dep't 1928), where the directors were refused recovery on the ground that their terms of office had expired. This decision was later reversed on the ground that directors may legally appear before the court and suggest suitable means for the dis- 
the court, expressed in the reversal of the Stoddard case, that to allow the directors recovery would be virtually permitting them to use the property for any purpose they saw fit. As a result of these cases, it may be said that at present in America surviving directors will be regarded by the courts as entitled to act, for the preservation of assets of the corporation, as trustees for the shareholders; and that non-compliance by reason of vis major with many of the technical charter requirements will not be fatal to their case.

The English cases have likewise run into the problem of passing upon the authority adhering in the directors of nationalized companies. While most of the suits in behalf of Russian companies have been brought by agents of the company and local managers, one case has arisen in which the problem of the rights of the directors was presented squarely before the court. In Woronin $v$. Huth four fugitive directors out of an original board of seven were allowed to recover a debt owed to the Russian company as "de facto" directors. Although the rights of directors have been questioned in several cases where the issue has not arisen directly, ${ }^{55}$ the conclusion to be drawn from the English cases is that where directors appear in sufficient number, even though they have not complied strictly with the provisions of the corporate charter with respect to meetings and elections, the courts will construe their power to act almost as liberally as will the American courts.

Prior to recognition of the Soviet government by France the reconstitution of Russian companies in that country by transplantation of the board of directors ${ }^{\text {so }}$ and the continuation of business in complete disregard of the Soviet decrees was permitted. Thus a draft signed by the directors of a bank in Russia after the nationalization decrees was held to be enforceable against the branch of the bank in Paris. 57 The courts also admitted the right of directors to replace members of the board by co-option if that process was performed by the proper parties under Russian law, ${ }^{58}$

Following recognition, one of the obvious signs of the exis-

posal of the funds involved. Mratter of Second Russian Ins. Co., 250 N. Y. 449,166 N. E. 163 (1929).

54 Supra note 26.

55 Sea Ins. Co. v. Rossia Ins. Co. supra note 24 (a proceeding to garnish the debt owed the Russian company); The "Jupiter," supra note 26, where the court in allowing one of the plaintiffs, the French liquidator of the Russian company, to recover, rejected the plea of the other plaintifr, the directors of the company.

56 Banque Russe pour le Commerce Etranger, Trib. Comm. Seine, January 16, 1922 (1923) 50 CLUNET 539.

57 Kharon $\nabla$. Banque Russe pour le Commerce et l'Industrie, supra note 34.

38 Ibid. See also Vlasto v. Banque Russo-Asiatique, supra note 34. 
tence of a de facto Russian company in France has been the presence of a functioning board of directors. ${ }^{59}$ Where a de facto company has not been established, the directors can neither sue ${ }^{60}$ nor be sued ${ }^{61}$ in their corporate capacity. In one case, however, where assets of a Russian company in the United States had been recovered by Russian directors, the French court has taken jurisdiction over a claim which a creditor of the Russian company sought to enforce against either the corporation or the directors as individuals. ${ }^{62}$ The suggestion has been made that the theory upon which the directors hold over in France is the presumption that their powers are tacitly renewed by the shareholders. In situations where such a theory obviously becomes untenable an alternative is advanced; it is argued that, provided the shareholders have not revoked their authority, the directors have the power to conserve the corporate assets so long as no court decides to the contrary. ${ }^{03}$

Although in an early case ${ }^{64}$ the rights of the directors were sustained by a Swiss court even though their term of office had expired, since the Hausner case, ${ }^{65}$ which found that Russian corporations had been dissolved both in Russia and abroad, the directors have no standing before the courts of that country. In Germany the powers of the directors were not discussed in the Ginsberg case ${ }^{66}$ since the directors were not parties to' the suit, but in holding that the Russian corporation had been dissolved by the Soviet decrees the implication was clear that the directors in Germany also have no standing in court.

Thus where the corporation is found to have been dissolved by the Soviet government, the directors have no standing. But where the corporation has not been held dissolved, it becomes a question of judgment on the part of the court, applying broad rules of equity rather than enforcing the technical requirements of the charters of the corporations, to determine whether the directors should be allowed to recover the assets in question in the name of the corporation. The Mejdumarodny case sets out the problem as follows: will the directors, such as they are, be allowed to recover, or are the funds to remain for an indefinite time without a claimant? The harshness of the latter alternative seems somewhat mitigated, however, by those courts which,

\footnotetext{
59 Banque Russo-Asiatique, supra note 37.

60 Banque de Sibérie v. Vairon, supra note 39.

61 Kamenka and Epstein v. Cahn, Trib. Comm. Seine, January 11, 1927 (1927) 54 CluNeT 362.

62 Khorosch v. Rossia, Kamenka et al., Cour d'appel de Paris, January 7, 1928 (1928) 55 CLUNET 687.

63 Note by Tager (1928) 55 Clunet 688.

at Comptoir d' Escompte v. Sosnowice, supra note 46.

65 Supra nóte 47.

60 Supra note 45.
} 
while not permitting the directors to recover, suggest some form of guardianship of the assets for the benefit of the shareholders and creditors.

Shareholders. Since the American courts have never contemplated that the Soviet government should be allowed to take possession of the assets of Russian corporations in the United States, the disposition of these assets resolves itself into the question whether the directors should be given them to hold on behalf of the corporation, or whether they should be allowed to remain where they are, in the hands of debtors, on deposit in banks, or in the possession of Insurance Commissioners, to be held there for the benefit of the shareholders and creditors.

The latter view has prevailed in a few cases. Thus in the Stoddard case, the court, in refusing to allow a recovery by the directors, declared:

"Though this property in form belongs to the corporation, in fact, if it has not been confiscated, the policy holders, creditors, and shareholders are eventually entitled to it. Certainly it does not belong to the directors to do with as they will." of

The rights of the shareholders here appear to be set up as against those of the directors acting in behalf of the corporation. That the court has not taken such an approach very seriously, however, is proved by the decision in the First Russian Insurance Co. case, ${ }^{68}$ where recovery of corporate property in the hands of the Superintendent of Insurance was allowed by the directors of a Russian company despite the decision in the Stoddard case. The ground of the decision was that no danger existed of double liability to the debtor in a foreign jurisdiction, as presumably the Superintendent of Insurance had no funds abroad which

57 Supra note 8, at 165,147 N. E. at 708. See also Andre v. Behn, 211 App. Dir. 380, 393, 208 N. Y. Supp. 65, 77 (2d Iep't 1925), where recovery to an agent of the corporation was refused as it was felt "no protection whatsoever is given to the other stockholders' rights; and plaintiff, a minority stockholder, is, by the judgment, made a custodian or practical receiver of the corporate property, without any security to insure a proper liquidation of the company's assets for the benefit of those clearly entitled thereto." In affirming this decision the court declared: "As a stoclholder suing in a representative capacity in the right of the corporation he has not made out a cause of action, since no waste of corporate assets is threatened." 240 N. Y. 605, 606, 148 N. E. 724 (1925). A recent decision of the Appellate Division, In re Beha (First Department, Misy 29, 1930), denied recovery of the surplus funds of Russian insurance companies in the hands of the State Department of Insurance to the exiled directors of the companies. The right of the shareholders to these funds was indirectly recognized, but distribution was to be suspended until the funds could be transmitted to a liquidator of the corporation at its domicile abroad. 
could be reached by the Soviet government. In the Mejdunarodny case the court also rejects the position of the Stoddard case and allows recovery of the debt by the directors to be held in trust for the shareholders. Thus it would seem that for purposes of recovering assets in this country, the shareholders are considered to be properly represented by the directors.

The only English case discussing the rights of the sharenolders at any length is the Woronin case which allowed recovery by directors of assets of the company in England. Here the shareholders presented deposit receipts for some of the shares accounted for. They had met in England following notice published in the English press, the notice also having been sent to Russia although no evidence of its publication was presented. The court declared:

"I think the shareholders who have disengaged themselves from the Russian jurisdiction are entitled to say that they are still shareholders of an existing company and are entitled to the benefit of any rights attaching to that status outside Soviet dominion." 69

In companies which are recognized under the de facto theory in France the shareholders apparently continue to enjoy the ordinary privileges accorded them by the charter. In one case where the shareholders sought to compel the directors to call a shareholders' meeting, the court, after examining the charter with care, ruled that it would enforce the shareholders' rights only as they were there expressed. ${ }^{70}$ It would seem that the shareholders are allowed to participate in the distribution of the assets of corporations that have been ordered to dissolve although no cases bearing directly upon the question have been found; certainly ordinary creditors of the companies have been given protection. ${ }^{71}$

In Germany and Switzerland where the corporation is deemed to have been dissolved, the courts nevertheless seem to recognize the existence of a right in the shareholders to share in the distribution of the assets within the forum. Thus in the Ginsberg case the court, after denying that the Soviet government had become entitled to the assets, appeared to suggest the alternative that they belonged to the shareholders. ${ }^{22}$ The Swiss

\footnotetext{
6s First Russian Insurance Co. v. Beha, 240 N. Y. 601, 148 N. E. 722 (1925).

${ }^{68}$ Supra note 26.

70 Banque Russo-Asiatique, Cour d'Appel de Paris, May 27, 1927 (1928) 55 CLUNet 126.

i2 Khorosch v. Rossia, Kamenka et al., supra note 62.

72 "No definite assertions have been made by the parties in regard to the question in whom the property of the bank would be vested, whether in shareholders of the corporation or in other legal representatives, on dis-
} 
courts have also given indications that they consider the creditors and shareholders entitled to the property. ${ }^{73}$

It thus appears that the real parties in interest, the creditors and the shareholders, will be protected. Where the directors are allowed to recover, on the assumption that the corporation is a continuing entity, it is on the understanding that they hold the funds for the creditors and shareholders. Where the directors are refused recovery there is a strong indication that the shareholders might be more successful. By very different routes the courts of countries that have or have not recognized the Soviet government or the decrees of the Soviet government, in the final analysis, arrive at much the same conclusion as to who is entitled to the funds. The conclusion here reached is strengthened by an examination of the closely related problem of the rights which the Soviet government has been able to establish to the foreign assets of the nationalized corporations.

\section{RIGHTS OF THE SOVIET GOVERNMENT}

The rights of the Soviet government to the assets of nationalized Russian companies in this country have not been passed upon directly by the American courts since, in the absence of recognition, it has been denied the capacity to sue. ${ }^{24}$ In some of the American cases, however, the question whether the Soviet government can recover such assets in countries where it is accorded recognition has played a significant part. For the fear has been frequently expressed that a debtor who is compelled to pay a debt to the representatives of a Russian corporation in the United States may be subjected to double liability if he possesses assets in a country which has recognized the Soviet government and given full extraterritorial effect to its confiscatory decrees. Thus in the Stoddard case Judge Lehman expressed this idea as follows:

solution under the Russian law which was in force until December 14, 1917." Ginsberg v. Deutsche Bank, supra note 42.

${ }^{73}$ In Banque Internationale de Commerce de Petrograd $\nabla$. Autorite de surveillance des tutelles de Geneve, Trib. Fed., November 2G, 1925 (unpublished, but discussed in Tiefenau, op. cit. supra note 7, at 161) the Federal Tribunal declared that it could not be doubted that the shareholders were interested in the disposition of the assets of the Geneve branch of the Banque Internationale and further made the statement that the managing director of the branch could be held responsible by the shareholders or the creditors of the bank. Furthermore the Conseul d'Etat of Geneve in a jetter of February 20, 1925, made the statement that the assets of the branch belonged either to the Peoples Bank (Soviet) or the shareholders. Ioid. The former alternative was excluded in the Wilbuschewitsch decision, infra note 96 , leaving only the latter as a possibility.

74 Supra note 5. 
"May we regard as similarly remote the possibility of such a second recovery in the courts of a foreign nation? . . . We recognize one source of law; most of the nations of Europe look to another sovereign as its source . . . Our inability to protect by our judgment this defendant against a second recovery upon the same cause of action presents a strong consideration against assuming jurisdiction in this action." 75

The extent to which these fears have proved to be well founded therefore becomes an important consideration.

Title to property by virtue of confiscatory decrees of a foreign state has been recognized by the courts in a limited category of cases. Where a former owner of property confiscated in a foreign country identifies such property in the forum in the hands of someone holding it as an agent or purchaser from the confiscating government and sues for its repossession on the grounds of a tortious taking in the foreign country, it has been held by American, ${ }^{70}$ English, ${ }^{77}$ German ${ }^{78}$ and Italian ${ }^{70}$ courts that the claims of the former owners are invalid in all cases where the foreign government has been recognized..$^{80}$

${ }^{75}$ Supra note 8 , at $167,168,147$ N. E. at 708,709 .

${ }^{76}$ Oetjen v. Central Leather Co., 246 U. S. 297, 38 Sup. Ct. 309 (1917) (recovery by former owner of hides seized under requisition by Villa and subsequently imported into the United States refused). See Underhill v. Hernandez, 168 U: S. 250, 18 Sup. Ct. 83 (1897).

$\pi 7$ Luther v. Sagor, [1921] 3 K. B. 532 (replevin of marked lumber of plaintiff company seized in Russia and brought into England denied); Princess Paley Olga v. Weisz, [1929] K. B. 718 (replevin of works of art confiscated from plaintiff in Russia and sold in England denied). Houghton, op. cit. supra note 7 .

${ }^{78}$ Caucasian Licorice Co. v. Katz, Landgericht, Hamburg, June 13, 1924 (1925) 1 OSTRECET 165 (dispossessed owners of confiscated merchandise unable to regain possession).

78 R. S. F. S. R. v. Römische Schwefelgesellschaft, Court of Cassation.of Italy, April 25, 1925 (1925) 1 OsTrecer 178 (former owner could not recover property confiscated in Russia when it was imported into Italy).

80 There is some dispute as to what should happen to property confiscated and brought into a country which has not recognized the confiscating government. The lower court decision in Luther v. Sagor, supra note 77, allowed the former owner to recover, the case being reversed following recognition. Similarly, recovery by the former owners was allowed in Bouniatian v. Soc. Optorg, Trib. Civil Seine, December 12, 1923 (1924) 51 CLUNET 133 and Federazione italiana dei consorzi agrari di Piacenza v. Comm. per il commercio estero del la R. S. F. S. R., Trib. Civil Roma, January 26, 1923 (1923) 75 GUIRISPRUDENZA ITALIANA $I, 2,131$. The view is generally supported by European writers. La revolution bolshevique et le statut juridique des Russes (1924) 51 Clunet 5. The case of Underhill v. Hernadez, supra note 76, however, does not appear to support the proposition. Chief Justice Fuller, in rendering the opinion of the court declared: "Every sovereign State is bound to respect the independence of every other sovereign State, and the courts of one country will not sit in judgment on the acts of the government of another done within its own territory. Redress of grievances by reason of such acts must be obtained through the means open to be 
At first thought, in view of the rule that political recognition "is retroactive in effect and validates all the actions and conduct of the Government so recognized from the commencement of its existence," ${ }^{81}$ it would appear that recognition is the sole and conclusive factor in determining whether effect to decrees, whatever their nature, is to be given in a foreign country. This was the implication of the Stoddard case and it has been supported by some commentators. Thus Mr. Fraenkel writing in 1925 views recognition as of itself giving some interest to the recognized government in the foreign property of nationalized companies:

"There is grave danger, however, that as a result of such suits property of nationalized corporations may come into the hands of irresponsible persons, to the detriment, not only of the Soviet Government, but also of creditors and stockholders not before the court. Recognition of Soviet Russia in the near future will further complicate such cases because of the retroactive effect which will be given to such recognition." 82

But this is going much further than the holdings of the cases warrant. The decisions cited above refer to property actually seized in the foreign state; ${ }^{83}$ the plaintiffs are former owners, who are trying to upset the title of the defendants claiming under the foreign government. In such a situation the courts have held as legally valid the acts occurring abroad. In other words, here they will not go behind the legality of the foreign transaction,

But if the property in question has not been actually seized by the foreign state because it has been located at all times since the confiscatory legislation outside of that state, it is quite a different matter. The plaintiff is the confiscating government or someone claiming under it; the courts of the state of

availed of by sovereign powers as between themselves. Nor can the principle be confined to lawful or recognized governments or to cases where redress can manifestly be had through public channels." 168 U. S. at 252, 18 Sup. Ct. at 84; cf. decision below, 65 Fed. 577 (C. C. A. 2d, 1895). It is pertiment to note, however, that the Venezuelan government had been recognized by the United States at the time the court rendered the decision, even though it had not when the acts complained of by the plaintifi had occurred. In Banque de France v. Equitable Trust Co., supra note 5, replevin of gold belonging to the Soviet State Bank alleged by the plaintiff to have been seized from it in Russia was refused. See also Borchand, The Validity Abroad of Acts of the Soviet Government (1921) 31 YALE L. J. 82.

81 Oetjen v. Central Leather Co., supra note 76, at 302, 38 Sup. Ct. at 311.

B2 Fraenkel, op. cit. supra note 7 , at 566. See also Wohl, op. cit. cupra note 44.

${ }^{83}$ Trotter, Extraterritorial Operation and Effect of Confiscatory Decrees of thie Soviet Government (1925) 3 N. C. L. RET. 88, discussing the older cases on this point with reference to the effect of recognition. 
the forum are requested to give effect to the decrees of the foreign state by allowing the plaintiffs to seize the property located in the forum. They are in fact asked to enforce the decrees in the forum against property under the protection of the courts of the forum. In this situation the courts have examined the decrees in question, and, if they are contrary to the public policy of the forum, they will not be enforced regardless of whether recognition has or has not been accorded the foreign state. The basis for this refusal is the exception in the conflict of laws of "public order" or "public policy," ${ }^{84}$ which Dicey has stated in its broadest terms as follows:

"English Courts will not enforce a right otherwise duly acquired under the law of a foreign country ... where the enforcement of such right is inconsistent with the policy of English law, or with the moral rules upheld by English law, or with the maintenance of English political and judicial institutions." 85

An American court has defined this rule as follows:

"The well known exception . . . that the laws, which are to be admitted in the tribunals of a country where they are not made, are not to be injurious to the state, or the citizens of the state, where they are so received ...." ${ }^{86}$

The exception of public order has been invoked in a wide variety of situations, ${ }^{87}$ and particularly frequently in opposition to claims based upon confiscatory legislation. The most famous cases prior to the flood of litigation involving Russian corporations were those arising out of the confiscation of the property and the dissolution of the order of the Carthusian monks by the French government in 1901.

The religious order of the Carthusians was profitably engaged

84 Habicht, The Application of Soviet Laws and the Exception of Public Order (1927) 21 AM. J. INT. LAW 238, 240: "The exception of public order appears everywhere as the generally adopted rule to prevent inequitable consequences of any theory, which admits the recognition of foreign laws."

85 DICEY, CONFLICT OF LuWS (4th ed. 1927) 27.

86 Prentiss v. Savage, 13 Mass. 20,23 (1816).

${ }_{87}$ The Duke of Brunswick, overthrown by a revolution, fled to France with an amount of personal property. A decree was issued by his successor to the throne declaring him a spendthrift and naming a guardian over all his property. The French court refused to give effect to the decree in France on the grounds that "its form, the authority from which it proceeds, the person to whom it applies, the circumstances in which it was issued, the reasons for its issuance, indicate its essentially political character." Le duc de Cambridge v. Le duc de Brunswick, Cour Royale, January 16, 1836 (1836) SIREY II, 70, 78. Where by a special decree the Emperor of Russia forbade Count Potocki to dispose of his property, the French courts refused to enforce this order against the count who owned real property in France. Rosa Catana v. Potocki, Trib. Seine, May 7, 1873 (1875) 2 Clunet 20. 
in the manufacture of a liqueur known as "Chartreuse" by a secret process protected by trade marks in many foreign countries. Expelled from France they re-established themselves in Italy and Spain and continued to manufacture their liqueur. The French liquidator sought to have the patent rights of the order transferred to himself. He was opposed by the monks who sought to preserve their property outside of France. The Federal Tribunal of Switzerland denied the claim of the French liquidators, giving as its grounds the following:

"It is not necessary in order to support this view to invoke the odious character of the Law of 1901 . . . It is sufficient to recall that political acts have validity only within the country where they are accomplished and their recognition in foreign countries is opposed, in the absence of special circumstances, to the principle of sovereignty of that state . . . Admitting even that the French Law of 1901 had certain effects in private law, it nevertheless remains true that they would not be recognized in a state whose public law does not permit the confiscation of the property of individuals." 88

The House of Lords ${ }^{89}$ took the same view as the Tribunal Federal of Switzerland but based its refusal to give title to the trade mark in England to the French liquidator and those claiming under him upon the ground that the decree in question had no extraterritorial effect because there had been no intent that it should be so regarded..$^{90}$

So, in states which have recognized the Soviet government the exception of public order has been employed to prevent the seizure of the property of Russian nationals and corporations located in the forum by the Soviet government claiming title under the confiscatory decrees. The most important case to test the title of the Soviet government to such property, arose out of the liquidation in France of the Ropit Company, a Russian navigation company. ${ }^{91}$

The suit was brought by the Soviet Ambassador against the provisional administrator of the Ropit Company, who had, previ-

${ }^{88}$ Compagnie fermière de la Grande Chartreuse v. Rey, Tribunal Federal, July 11, 1913, 39 R. O. II. 640, 652. See Pillet, La Marque Chartrcuse (1907) 3 REv. DE DR. INT. Pruv. 525, 533. The Law of 1901 is characterized as a "political law, having no effect abroad ... it is not to be doubted that this law is impressed with an odious nature which is found in confiscatory laws. It must produce no effect abroad."

${ }^{89}$ Lecouturier v. Rey, [1910] A. C. 262.

90 A German court allowed the liquidator to recover on the theory that in Germany a foreigner can only register the trade mark he has in his own country. It is the property in his country that is protected by the German trade mark. Lacouturier v. Rey, Trib. Civ. Hamburg, February 23, 1906 (1907) 3 Rev. DE DR. INT. PRrv. 415.

gz Etat Russe v. Ropit, Trib. Comm. Marseille, April 23, 1925 (1925) 52 CLUNET 391. 
ous to the recognition of the Soviet government, been appointed by a French Court at the request of shareholders, refugee directors and other interested parties to administer the assets of the company. The Ambassador demanded that the property of the Ropit Company situated in France be turned over to him on the grounds that the decree of January 26, 1918, nationalizing all the property of the Ropit Company, must, in view of the recognition accorded the Soviet government by the French government, be valid in the eyes of the French court. The lower court denied the plaintiff recovery for the reason that the decree of nationalization, whose application in France was in question, gave no compensation to former owners of the property and was therefore confiscatory in character. The enforcement of such a decree in France, it was felt by the court, would be contrary to French public policy. It was pointed out, moreover, that the Soviet government had itself, by an official circular of the Commissariat of Foreign Affairs, stated that "the legislation of each country, with regard to property rights, is applicable only within the territorial limits of that country. . . ."

The Soviet government thereupon countermanded its circular and took an appeal. The appeal, however, was rejected by the Court d'Aix which declared:

"It is inadmissible that the French state in recognizing the Soviet Government de jure is ipso facto precluded from refusing to apply any of the provisions of [Russian] law which seem to it contrary to its own conception of national public order." 02

The case was appealed again by the Soviet government to the Court of Cassation, the court of last resort. In denying the appeal, this court reviewed the points raised in the lower courts and entered in greater detail into considerations of public policy :

"Whereas in principle the courts of one state, when they have to pass upon a legal question which has its roots in foreign legislation, must apply foreign law, this rule is obligatory only where the application of foreign law or the recognition of rights acquired under foreign law do not conflict with the principles or the application of domestic laws essential to the maintenance of public order. . . Whereas the Soviet decree of January 26, 1918 nationalized the Russian mercantile fleet without just compensation being granted to the dispossessed proprietors, this decree thereby instituted a mode of seizing property which French courts cannot recognize. . . ." ${ }^{93}$

This decision of the highest tribunal of France thus seems defin-

92 December 23, 1925 (1926) 53 CLUNET 667, 668.

${ }_{93}$ March 5, 1928 (1928) 55 CLUNET 674. 
itely to have rejected the enforcement of confiscatory foreign legislation against property outside the jurisdiction of the Soviet state at the time of the decrees and within the jurisdiction of the French Courts at the time of suit.

A similar decision was rendered in England where a vessel belonging to the same navigation company, which had left Russian waters before the Soviet government had actually seized it, was subsequently given over to the Soviet Embassy in London by the master of the ressel without authorization of his principal, the old Russian company. The ship was then sold by the Soviet gorernment to the defendant. The court allowed the plaintiff to recover the ressel from the defendant on behalf of the Russian company, declaring in the course of its decision:

"If the Jupiter was not within the territory of the R. S. F. S. $R$. I do not see how the mere passing of a decree could transfer the property . . ." s4

Again, in another case involving a debt owed to a Russian insurance company, the King's Bench declared:

"Effective as such legislation may be within the limits of Russian territory, it cannot determine the ownership of property locally situated in this country, such as debts owing from debtors here." 95

In the recent case of Wilbuschewitch $v$. Zurich, the Swiss Federal Tribunal reasserted, in substance, the objections to foreign confiscatory legislation voiced in the Chartrense decision:

"Swiss law regards as contrary to public order and morals the appropriation by the Russian State of the assets of the Russian banks without the assumption of their liabilities guaranteed by these assets, and neither the Russian State nor the Peoples Bank can be regarded as the successor of the Banque de Commerce de Sibérie in its relations with the Banque Federal." 06

Similarly, the most recent decision of the German courts explicitly declares that any appropriation of the property of a bank by the Russian state by virtue of the confiscation of the assets of the former banks by nationalization, "cannot be recognized by reason of Art. 30 of the EGBGB." ${ }^{92}$ A few scattered

${ }^{24}$ The "Jupiter," [1927] P. D. 122, 144. See supra note 26.

95 Sedgrick, Collins \& Co. v. Russia Ins. Co., 22 Ll. L. R. 475, 476 (1925)

96 Tribunal Federal, July 13, 1925 (1926) 53 Cluver 1110, 1113.

97 Ginsberg v. Deutsche Bank, supra note 42. Article 30 of the EGBGB: "The application of a foreign law is excluded if the application would contravene good morals, or the purpose of a German law." 
cases indicate that the courts of other countries have arrived at substantially the same result. ${ }^{05}$

Writers are in conflict as to the importance that should be accorded the theory of public order. Some distinguish the Soviet nationalization measures from the confiscatory decrees dealt with in the older cases on the ground that the Soviet decrees are not purely political acts but economic measures and the "foundation of the entire private and public legal order of Soviet Russia." This consideration, however does not appear to have weighed very heavily with the courts. The one decision found out of line with these referred to above was rendered by a tribunal of the Georgian Republic shortly before that Republic became absorbed by the Soviet Union. ${ }^{10 u}$. The case is more a curiosity than a warning.

It would appear from the foregoing that the New York Court of Appeals was quite justified in the Mejdunardny case, both by the practice of foreign courts and by authority, in dismissing the danger of double liability as a determinative consideration. As Chief Judge Cardozo remarked:

"The danger [of double liability] is not imminent, as the course of events since our decision in Russian Reinsurance Co. $v$. Stoddard sufficiently attests. France recognizes the Soviet Republic as a member of the family of nations. Yet till now at least, it has failed to give effect to titles having their basis in decrees of confiscation . . . Negligible is the risk that by any judgment in its domicile it will be compelled to pay again. Whatever risk it runs abroad, is one that it assumed as part of its business of a bank." 101

There remains the somewhat improbable contingency that following recognition, American courts would feel obligated to allow the Soviet government to recover from local debtors sums

${ }^{98}$ The Supreme Court of Denmark has held that the Russian Church in Copenhagen which belonged to a religious corporation nationalized by Soviet decree, despite de jure recognition of that government, would not be placed in the possession of representatives of the Soviet government. The Council of the Russian Orthodox Community in Copenhagen v. The Legation of the R. S. F. S. R. in Copenhagen, Supreme Court of Denmark, October 22, 1925 (1925-26) ANN. Dig. of INT. L. CASES 24. See also the Swedish decision supra note 49.

${ }^{89} \mathrm{Wohl}$, op. cit. supra note 44 , at 635 . Dr. Wohl's view is opposed by Robinowitsch, op. cit. supra note 44 . See also Champcommunal, op. cit. supra note 34 .

100 Ships of a nationalized Russian company were sold by the Russian company's agents.during the revolution. On arrival at Batoum, the Soviet Consul claimed them by virtue of the nationalization decree. Recovery by the Soviet Consul was allowed. S.S. George and Edwich, Consul of the R. S. F. S. R. v. Italian Consul, Republic of Georgia, October, 1922 (1923) BuLL. INS. INTERMEDIARE INT. 336.

101 Supra note 14 , at 39,170 N. E. 485. 
owed to Russian nationalized corporations. The Stoddard case, however, was careful to point out that the responsibility for making all Soviet actions valid would be upon the State Department and suggests that unconditional recognition is not the only road open to executive officials:

"Nor will we assume that the State Department will ever enter into such relations with the Soviet Government as might compel our courts to enforce such a claim." 202

Thus either by treaty in granting recognition, if indeed recognition is ever granted to the Soviet government, or by the proper application of the exception of public order, such as is suggested above, the danger of double liability in the forum may be successfully avoided.

Conclusion. From this brief survey of the decisions, it would appear that the problem of the effect to be granted Soviet legislation has been solved by the courts in a variety of ways. Any criticism of the theories employed must take into consideration the peculiar nature of the issues. The problem is really, though it may not be admitted, to give the least possible extraterritorial effect to Soviet legislation which is contrary to the public policy of the forum. It is agreed that the Soviet government is not entitled to recover the assets of the nationalized Russian corporations abroad. Why does it not follow that where the debt is admitted the plaintiff corporations must be allowed to recover? Certainly no court can honestly decry the demoralizing effects of Soviet legislation on the one hand and sanction an equally unjustified confiscation of the corporate property within the forum by its debtors on the other. Yet this is, in effect, the result that flows from denying to the corporation the right to sue. Anglo-American courts have in most cases avoided such a result. The English expedient of denying that the decrees by their terms dissolved the corporations is somewhat unsatisfactory since it leaves the door open to legislation that would, by its terms, have such legal effect, a situation which would require the courts, if they were to deny it effect, to fall back on some other theory. The American doctrine, as enunciated by Chief Judge Cardozo, really goes deeper into the roots of the question. If it is contrary to the public policy of the forum to aid in carrying out a wholesale dissolution and confiscation of assets of corporations outside of Russia, the courts should extend the exception of public order to refuse effect to such decrees both in respect to dissolution and confiscation, whether the state promulgating them has or has

102 Supra note 8 , at 166,147 N. E. at 708 . 
not been recognized. Once this step has been taken and the corporation is regarded as continuing in the forum for purposes of suit, the only problem remaining is for the court to determine that the party plaintiffs, directors, agents or shareholders of the corporation, appear in good faith and are the best available representatives of what remains of the corporation. It is approximately this attitude which has been adopted in the recent decision of the New York Court of Appeals. 